\title{
Evaluation of the Nutritive Importance of Fresh and Dry Cyperus esculentus (Tiger nut) Available in Ogbomoso, Oyo State, Nigeria
}

\author{
${ }^{1}$ Babatunde, P. Ayoola and ${ }^{1}$ Ibikunle, G. J*and ${ }^{1}$ Adebola, O. Akintola* \\ 1 Department of Science Laboratory Technology, Ladoke Akintola University of Technology, \\ P.M.B 4000, Ogbomoso, Oyo State, Nigeria. \\ * Corresponding authors: aoakintola@lautech.edu.ng, gjibikunle@lautech.edu.ng \\ $+2348189470244,+2347069627168$
}

\begin{abstract}
Fresh and dried Cyperus esculentus nuts were obtained from a local market (Sabo market) in Ogbomoso, Oyo State, Nigeria. These nuts are chew, serve as snacks and used as sources of food and medicine in Nigeria. In this study; proximate, mineral content (using AAS), vitamins and sugar compositions were determined using standard methods [1] The results of the proximate composition revealed that the dry nuts contained higher amount of the nutrients present (fat $35.43 \%$, protein $9.70 \%$ and ash $4.25 \%$ ) than the fresh nuts $(32.13 \%, 7.15$ $\%$ and $3.97 \%$ ). The result of the mineral content shows that, calcium, iron and manganese were higher in the dry nut than the fresh nut.Sugar composition result shows that sucrose and glucose were the prominent sugar present and were higher in the dried nut than in the fresh nut.The result of the vitamin compositions revealed that vitamin A was equally present in both fresh and dried nut, while fresh nut contained higher amount of vitamin $\mathrm{B}_{1}(2.25 \mathrm{mg} / 100 \mathrm{~g})$ and $\mathrm{B}_{3}(3.47 \mathrm{mg} / 100 \mathrm{~g})$ other vitamins were in traces in both nuts. The result of this study showed that both fresh and dried nuts of $C$. esculentus are of high nutritional value based on their proximate, mineral, vitamin and sugar contents.
\end{abstract}

Keywords: Proximate, mineral, vitamin, sugar, nuts

DOI: $10.7176 / \mathrm{JBAH} / 11-16-05$

Publication date:August $31^{\text {st }} 2021$

\section{Introduction}

Cyperus esculentus (Tiger nut) is a noxious weed which belongs to the family of Cyperaceae. It produces rhizomes from the base and tubers that are spherical [2], and is known by various names like Chufa (Spanish), Earth Almond, Rush nut, Water grass, Zulu nut, Nut grass and edible rush [3][4]. The nut of this plant is known by various local languages in Nigeria as 'Aya' (Hausa), 'Imumu' or Ofio (Yoruba) and Aki Hausa (Ibo) [5].

The nuts can be eaten raw, roasted, dried, baked or made into a refreshing beverage called 'kunnu' in Hausa language [6].

It has been reported that tiger nut helps in preventing heart attacks and cancer especially of the colon due to high content of soluble glucose [7]. In Egypt, It is used as sources of food, medicine and perfume [8].

Tiger nut milk is very nutritive and energetic drink, both for young and old. It is tremendously high in starch, glucose and protein. Also rich in mineral and has never been found to produce allergy [9]. It is also found to be useful as a flavoring agent for ice cream and biscuits [10].

This nut contains a good quantity of vitamin $\mathrm{B}_{1}$, which assist in balancing the central nervous system and helps to encourage the body to adapt to stress. It is also used in the treatment of flatulence, indigestion, diarrhea, dysentery and excessive thirst [11].

The nut has been reported to be carminative, diuretic, stimulant, aphrodisiac, emmanogogue and tonic [12]. When the nut is well roasted they are used as a substitute for coffee in Sierra Leone, it is made into a kind of Chocolate, therefore, it is widely regarded as having an aphrodisiac and medicinal effect [13].

It has also been reported to contained high dietary fibre content, which could be effective in the treatment and prevention of many diseases such as colon cancers, coronary heart diseases, obesity, diabetes and gastro intestinal disorders [14]. Oladele et al [15] reported that the nuts are excellent sources of some useful minerals such as iron and calcium which are essential for body growth and development. This research work intends to establish the nutritive values present in both the fresh and dried $C$. esculentus nut such as; nutrients, mineral, vitamins and sugar, in the Ogbomoso type of the nuts.

\section{Materials and Methods Sample collection and preparation}

Cyperus esculentus (Tiger nuts) were purchased from Sabo market (the centre of distribution of the nut to other parts of Ogbomoso land markets) in Ogbomoso, Oyo State, Nigeria (Plate1,2). The nuts were thoroughly picked to remove the bad, stones and particles. Three hundred gramme $(300 \mathrm{~g})$ of the fresh and dried nuts were weighed respectively and air dried for 30 days thereafter ground to powdery form using laboratory electric Mill. The powdered samples were air dried by spreading on a white cardboard in the laboratory for seven (7) days then transferred into a dessicator separately in order to be certified that all water molecules had dried off, thereafter, 
the samples were transferred into air tight sample bottles and kept for other analysis.

\section{Proximate Analysis}

Twenty gramme $(20 \mathrm{~g})$ of each sample was weighed and used for the determination of moisture content while other parameters like; ash content, crude fibre, crude protein, crude fat were determined using the air dried powdered samples and the carbohydrate content was estimated by difference, subtracting the sum of moisture, protein, fat, crude fibre and ash percentages from one hundred [1].

\section{Mineral Analysis}

The AOAC, method [1] was used for the determination of minerals in the test samples. Calcium and magnesium were determined by flame photometric method while iron, zinc, manganese and copper were determined by atomic absorption spectrophotometric method.

\section{Vitamin Analysis}

The composition of the water soluble vitamins like thiamine $\left(\mathrm{B}_{1}\right)$, riboflavine $\left(\mathrm{B}_{2}\right)$, niacin $\left(\mathrm{B}_{3}\right)$ and panthothermic acid $\left(B_{5}\right)$ were determined by the method of [16]. Vitamin A was determined using method of [1].

\section{Sugar Analysis \\ Sugar extraction}

Sugar were extracted from the samples using $25 \mathrm{ml}$ of hot $80 \%$ ethanol added to $1 \mathrm{~g}$ of each sample in a boiling tube and shaken on a vortex mixer. The materials were allowed to settle for $30 \mathrm{~min}$ and then filtered through a Whatman no.41 filter paper into a beaker. The extracts were heated until the ethanol was evaporated. $10 \mathrm{ml}$ water was added to each beaker to dissolve the contents (extracts) and transferred into $100 \mathrm{ml}$ volumetric flask. The beaker's content was washed and added to the volumetric flask and made up with distilled water to $100 \mathrm{ml}$ mark.

\section{Determinations of Sugar composition}

Anthrone method was used. $1 \mathrm{ml}$ solution of the sugar extract was pipette into a test tube and $1 \mathrm{ml}$ water as blank was pipette into another test tube, $6 \mathrm{ml}$ of anthrone-sulphuric acid reagent (which was prepared by dissolving $1 \mathrm{~g}$ of anthrone in $760 \mathrm{ml}$ of conc. $\mathrm{H}_{2} \mathrm{SO}_{4}$ plus $240 \mathrm{ml}$ of distilled water) was added and shaken on a shaker vigorously for $2 \mathrm{~min}$ and cooled.

Standard sugar (sucrose, maltose, glucose) solutions of range 10-50 $\mu \mathrm{g} / \mathrm{ml}$ were treated with anthronesulphuric acid reagent as above and the absorbances of the separate solutions of samples and their standards were read on a spectronic 21D spectrophotometer at wavelength of $490 \mathrm{~nm}$ [1].

\section{Results and Discussions}

The result of proximate composition shows that the fat $(35.43 \%)$, protein $(9.70 \%)$ and ash $(4.25 \%)$ contents in the dry nut were more than that in the fresh nut, while the fresh nut contained more crude fibre than the dry nut (Table1). The high dietary fibre content could be effective in the treatment and prevention of many diseases such as colon cancers, coronary heart diseases, obesity, diabetes and gastrointestinal disorders [14]. Fibre diets promotes the wave-like contraction that move food through the intestine, high fibre food expand the inside walls of the colon, easing the passage of waste, thus making it an effective anti-constipation, it also lowers cholesterol level in the blood, reduce the risk of various cancers, bowel diseases and improve general health and well being. Presence of high crude fibre improves glucose tolerance and is beneficial in treating maturity on set diabetics [17].

The amount of mineral content, especially, calcium, iron and manganese contained in the dry nut were little higher than the fresh nut (Table 2). Calcium helps in regulation of muscle concentrations, transmit nerve impulses and help in bone formation [18]. Iron is said to be an important element in the diet of pregnant women, nursing mothers, infants, convalescing patients and elderly to prevent anaemia and other related diseases [19].

Therefore, Cyperus esculentus nuts are good sources of iron. However, Manganese supports the immune system, regulates blood sugar levels and is involved in the production of energy and cell reproduction. It works with vitamin $\mathrm{K}$ to support blood clothing. Working with B-complex vitamins, manganese helps to control the effects of stress and also used in the management of diabetics [20].

The amount of the B vitamins were higher in the fresh tiger nut than in the dried nut, while vitamin A was little higher in the dried tiger nut than the fresh nut, the reason being that vitamin B's are water soluble while vitamin $\mathrm{A}$ is fat soluble, therefore the fat in dried nut was higher than the fresh nut (Table 3 ). Presence of vitamin A indicates the usefulness of this plant in sight management.

Sucrose, maltose and glucose were the prominent sugars present in the nuts, therefore, the dried nut contained more of these sugars than the fresh nut (Table 4). 
The high amount of fat, glucose, fibre, protein and carbohydrate in the $C$. esculentus nut make them ideal for healthy living and contribute to its nutritional qualities [21].

\section{Conclusion}

This study revealed that fresh and dry nuts contained all the nutrients that constitute balance diet and could serve as good sources of useful minerals which are essential for body growth and development. Therefore, the dry Cyperus esculentus nut is more nutritious than the fresh nut.

\section{REFERENCES}

[1] AOAC (1984). Official Methods of Analysis, $17^{\text {th }}$ edn, Association of official analytical chemistry, Washington D.C.

[2] Cortes, C., Esterw, M., Frigola, A., and Torregrosa, F. (2005). Quality characteristics of Horchata (a Spanish vegetable beverage) treated with pulsed electric field during shelf. Food Chem. 91: 315-319

[3] Shilenko, M.P., Kalacheva, G.S, Lisovski, G.N and Trubacher, I.N. (1979). Cyperus esculentus L. as a source of vegetable oil in a closed life support system. Kosm Biol. Aviakosm. Med. 13: 70-74

[4] Eteshola, E and Oraedu, A.C. (1996). Fatty acids composition of tiger nut tubers baobab seeds (Adasonia digitata) and their mixture. J. American Oil Chemical Society, 73:255-257

[5] Omode, A., Fatoki, O., and Olaogun, K.A (1995). Physico-chemical properties of some under exploited and non conventional oil seed. J. Agric. Food Chem. 11: 50-53

[6] Oladele, A.K and Aina, J.O. (2007). Chemical composition and functional properties of flour produced from two varieties of tiger nut (Cyperus esculentus). Afri. J. Biotechnol. 6: 2473-2476

[7] Osagie, A.U and Oka, O.U. (1998). Nutritional quantity of plant foods. Post harvest research unit. 22: 246249

[8] De vires, F.T. (1991). Chufa (Cyperus esculentus): A weedy cultivar or a cultivated weed, Econ. Bot. 45: $27-$ 37

[9] Belewu, M.A and Abodunrin, O.A (2008). Preparation of Kunnu from unexploited rich food source. Tiger nut (Cyperus esculentus). World Journal of Diary and Food Science. 1:19-21

[10] Cantalejo, M.J. (1997). Analysis of volatile earth almond (Cyperus esculentus L.). J. Agric. Food Chem. 45: 1853-1860

[11] Chevallier, A. (1996). The Encyclopedia of medicinal plants. Dorling Kindersley Press London. 48-51

[12] Chopra, R.N., Naya, S.I., and Chopra, I.C. (1986). Glossary of Indian Medicinal plants (including the supplement). New Research, pp. 18-30

[13] Burkil, H.M (1975). The useful plant of West Tropical African (2 ${ }^{\text {nd }}$ edn.). Royal botanical garden publisher.1:5-9

[14] Anderson, J.W, Smith, B.M and Crustafson, N.J. (1994). Health benefit and practical aspects of high fibre diets. Am. J. Clinical Nutr., 59: 12425-12475.

[15] Oladele, K.A, Osundahunsi, F.O, and Adebowale, A.Y (2009). Influence of processing techniques on the nutrients and antinutrients of tiger nut(Cyperus esculentus L). World .J. Diary and Food Science. 2: 88-93

[16] Okwu, D.E and Josiah, C. (2006). Evaluation of the chemical composition of two Nigerian Medicinal Plants. African. J. Biotechnology. 5(4): 357-361.

[17] Eromosele, I.C and Eromosele, C.O. (1993). Studies on the chemical composition and physicochemical properties of seeds of some wild plants: Plant for human Nutrition (Netherland) 43: 251-258

[18] Cataldo, C.B, DeBruyne, L.K and Whiteny, E.N. (1999). Nutrition and Diet Therapy Principles and Practice. $5^{\text {th }}$ Ed. Wadsworth Publishing Company an International Thomason Publishing Company U.S.A. pp: 35, 204

[19] Oluyemi, E.A., Akinlua, A.A., Adenuga, A.A and Adebayo, M.B. (2006). Mineral contents of some commonly consumed Nigerian foods. Science Focus. 11(1) 153-157

[20] Ayoola, P.B, Adeyeye, A and O.O.Onawumi (2010). Trace Elements and Major minerals Evaluation of Spondias mombin, Vernonia amygdalina and Momordica charantia Leaves. Pakistan Journal of Nutrition. 9(8): 755-758

[21] Sawonola, O.A., Akintunde, T.Y and Adedeji, F (2005). Nutritional and Sensory qualities of soymilk-kunnu blends. African J. Food and Nutri Sci., 5:1-12 


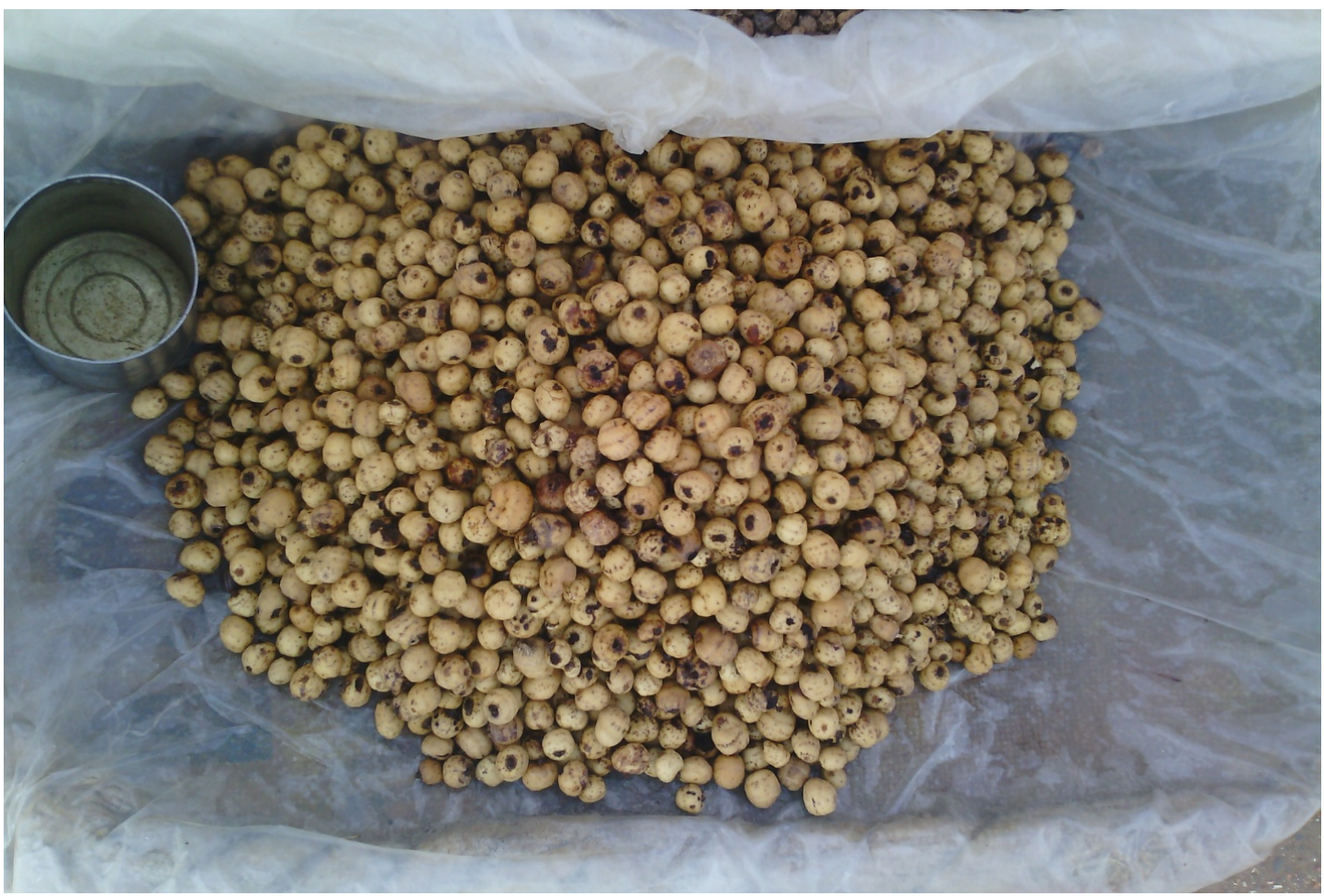

Plate 1: Fresh Cyperus esculentus (Tiger) nut

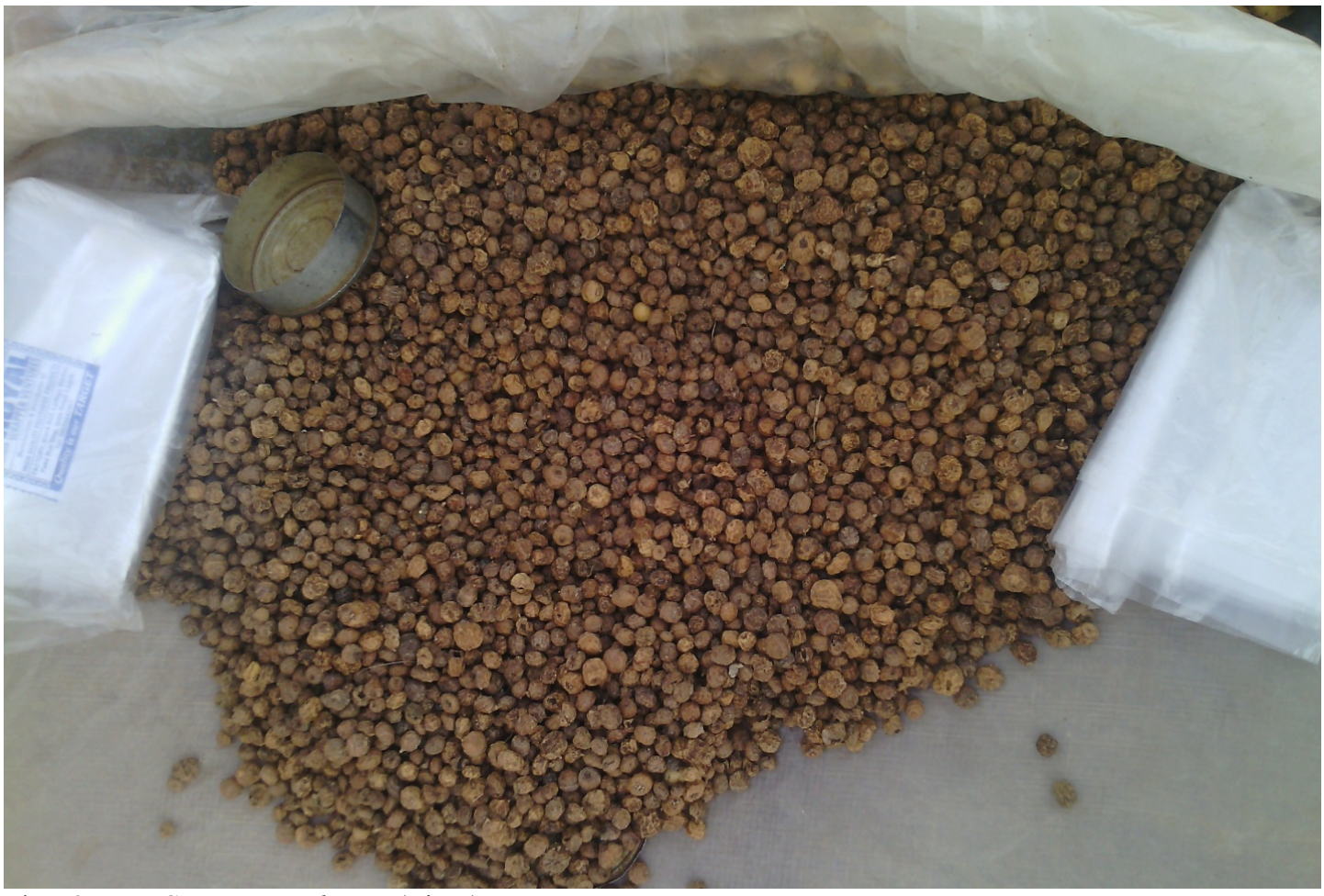

Plate 2: Dry Cyperus esculentus (Tiger) nut 
Table 1: Proximate Compositions of the Fresh and Dry C. esculentus (Tiger) nuts

Parameter

Moisture content $(\%)$

Crude fibre (\%)

Ash (\%)

Protein $(\%)$

Fat $(\%)$

Carbohydrate $(\%)$

Energy value $(\mathrm{kcal} / \mathrm{g})$

$$
\text { Fresh }
$$

$\begin{array}{ll}3.88 & 3.65 \\ 6.06 & 5.52 \\ 4.01 & 4.38 \\ 7.10 & 9.50 \\ 31.10 & 34.50 \\ 47.85 & 42.45 \\ 499.70 & 518.30\end{array}$

Table 2: Mineral Compositions of the Fresh and Dry C. esculentus (Tiger) nuts

Parameter

Calcium (ppm)

Magnesium(ppm)

Zinc (ppm)

Iron (ppm)

Manganese(ppm)

Copper(ppm)
Fresh

21.96

0.15

0.22

11.00

4.69

0.66
Dried

22.24

0.21

0.46

11.03

4.72

0.68

Table 3: Vitamin Compositions of the Fresh and Dry C. esculentus (Tiger) nuts

Vitamin

A (mg/100g)

$\mathrm{B} 1(\mathrm{mg} / 100 \mathrm{~g})$

B2 $(\mathrm{mg} / 100 \mathrm{~g})$

$\mathrm{B} 3(\mathrm{mg} / 100 \mathrm{~g})$

$\mathrm{B} 5(\mathrm{mg} / 100 \mathrm{~g})$ Fresh

3.086

2.25

0.15

3.47

0.72

Dry

3.167

1.67

0.09

2.56

0.55

Table 4: Sugar Compositions of the Fresh and Dry C. esculentus (Tiger) nuts Sugar

Sucrose $(\%)$

Galactose (\%)

Maltose (\%)

Fructose (\%)

Glucose $(\%)$ Fresh

8.63

0.35

2.19

1.04

4.91

Dry

9.50

0.69

2.47

1.36

5.81 